\title{
SHADES OF DISCIPLINE: PRINCESS DIANA, THE U.S. MEDIA, AND WHITENESS
}

\section{Larissa J. Faulkner}

The Princess Diana narrative is a rare text of a singular woman produced and marketed globally. Moreover, the Diana "myth" has been produced and disseminated during a time when sensationalism and the invasiveness of mass media know no formal boundaries. Diana may very well be the most photographed woman in the world (more so than Jacqueline Onassis or Marilyn Monroe). Perhaps we all could agree this once with controversial critic Camille Paglia as she sums up responses to Princess Diana:

It is an international obsession whose scale and longevity show that it is more than high-class soap opera or a reactionary wish fulfillment fantasy for American Anglophiles. . . Diana may have become the most powerful image in world popular culture today, a case study in the modern cult of celebrity. (Paglia 23).

The Diana narrative has developed and endured over sixteen years and has no real end in sight even though her reign as Princess of Wales is officially over.

In this essay I am interested in explaining how the United States popular media handled Diana's separation from Prince Charles in 1992 and masked this rupture in the representation of Diana as the ideal (white) woman. Feminist media critics have yet to pay serious attention to this text, perhaps because the image does not fit the norms of feminist media criticism. On the one hand, the US media rarely record Diana's spoken discourse so a critic cannot analyze a traditional public speaking text (cf., Dow 1991; Dow \& Tonn 1993). On the other hand, Diana is a real woman active in the public sphere, not the fictional character of a television show or movie who is often the object of analyses in much contemporary media criticism (cf., Dow 1990; 1994). I want to emphasize that when the United States media make Diana's speech inaccessible they have more room to speak for her and about her. In what follows I will not look at the Diana narratives in an attempt to get to her voice. Rather, I regard the articles I analyze (whether they quote Diana directly or not) as unique commentaries on cultural values regarding women in the United States. 
One might expect representations of women in popular culture to have changed considerably in the past 20 years because of some legislative and social changes affecting women's lives. But this case study of Princess Diana texts like other recent media criticism (Cloud 1996; Dow 1990, 1994; Hanke 1991) shows remarkably unchanged images. Instead, the media paints a thin layer of "progress" over traditional themes of femininity set by a dominant white norm.

The following analysis of Princess Diana representations in magazines, books and tabloids tracks five themes operative in both the Diana narrative and in dominant accounts of ideal white femininity: woman as beauty object, nurturer, victim, hysteric, and femme fatale. From these five themes I determine that the media, taken in sum, attempts to discipline images of Diana into a traditional standard of white femininity and temper any expressions of will. Moreover, I use theories of race to show how the media recuperates Diana's image back into the service of a sexist culture even after her split from Charles. I will argue that the media discipline Diana for leaving her Prince not by making her image less feminine, but by color-ing her femininity.

\section{Beauty Object}

Diana, a 5' 10" blonde (blonder now than 10 years ago), is extremely photogenic and her stylishness invites comments and admiration from those who see her photographs. Books have been written on her fashions alone (see, for example, Janaway 1984), and InStyle offered an eight-page shopper' s guide to Diana's fashions (Lague). Reportedly, she keeps her photogenic figure fit by dancing and swimming often.

Photographers frequently picture Diana resplendent in fine gowns and jewels. For instance, the cover of a recent $\mathrm{McC}$ Call's magazine features an upperchest-and-head shot of Diana smiling. A little red cloth from an off-the-shoulder evening dress shows, while red lipstick and gloss outline the pearly white teeth. Pearl earrings with diamond and ruby accents dangle on either side of her head. Her black-fringed blue eyes glance somewhere off to the reader's right. The headline for this cover shot is "Diana's Sweet Revenge: Inside Report from London," a title that gives the Princess power but situated within the ongoing narrative's context of victimization by her royal husband (Howell 100).

The impeccable beauty image remains even when the media discusses eating disorders or alcoholism. The cover for the People Magazine feature story, "Battling Bulimia: Diana's Diet Ordeal" shows the smiling Princess's head (this time in three-quarter profile) looking a little peaked and without much makeup. The only jewelry shown is a pair of unembellished golden hoops. An inset of the Princess on the left, however, shows her from waist-up in an evening gown with sparkling, dangling blue earrings. Although the cover reduces the Princess's glamorous image to a small box instead of a full-page cover, turning to the inside story on the eating disorder reveals five photographs of Diana in evening dresses. These photographs display her various thick and thin figures. However, the shiny and luxurious gowns and jewels obscure the significance of 
the diseased body.

Similarly, in Newsweek's article headlined "Private Lives: How the Fairy Tale Unraveled," the Princess smiles at the reader from the cover even though she faces the dissolution of her marriage and potential custody battles over her children. She perches on the edge of a gilded throne-like chair next to a standing Prince Charles. She wears a diamond tiara, an amethyst necklace and bracelet, and her large sapphire-and-diamond engagement ring. Her purple velvet evening gown is strapless, displaying the contours of her breasts. Inside, the magazine displays a photograph of Diana emerging from a car in a short skirt. The legs, though deeply bent, are half the length of the frame. The image also reveals the deepened cleavage that occurs as she ducks her head to exit the vehicle.

Regardless of the variety of events that prompt the articles, pictures of Diana show her in jewels, feminine clothes, and makeup-Western culture's typical feminine dress code. The jewelry and makeup reaffirm a cultural message that women's natural features are flawed and can be "fixed" or enhanced by purchasing cultural commodities. Kilbourne explains that "a woman is conditioned to view her face as a mask and her body as an object, as things separate from and more important than her real self, constantly in need of alteration, improvement, and disguise" (22). Moreover, after the industrial revolution, middle to upper class white women became consumers for their whole families and were supposed to display their husbands' wealth to its best advantage through fashion and other commodities. In this scenario, man makes the money; woman spends it (Mattelart 27).

The jewelry also bespeaks culture in another way. Some of Diana's tiaras and necklaces are antique heirlooms passed on to her by the Queen and Queen Mother (Wallace 23), yet gold and diamonds are not native to the British Isles. Given that the British Empire colonized much of the Third World, this jewelry symbolizes and may directly result from stolen raw materials and enslaved manual labor by people of color. Thus, the very construction and trappings of Diana as royalty symbolize imperialism. That these reminders of racism are unremarkable in a United States heavily engaged in issues of multiculturalism and affirmative action seems counter-intuitive. Here acceptance of such jewelry serves to naturalize race, gender and class hierarchy. How would one recognize a princess if she were not wearing such a crown?

\section{Nurturer}

Another popular photographic opportunity is Diana with children. The world knows Diana loves children - she was pictured with children at the kindergarten where she worked, and, before she had her own children, she was frequently photographed with children as she conducted her royal tours. Probably one of the most unflattering photographs ever published of Diana was at the baptism of Prince William (Hall 27). Seated on a couch, she cranes her neck at an odd angle while she sticks her finger in the baby's mouth. From this camera angle, her direct profile is shown to the camera-her nose appears large and beakish. 
But her expression is one of absorption with the infant, and the twist of her neck is similar to a mother bird' s. The only possible reason for reprinting this photograph over and over is that it captures Diana's "nurturing spirit."

Now that she has her own two children and is separated, the press provides us a text of her as a sad, dutiful mother (Paglia 24). The duties of a princess do not prevent Diana from picking her sons up from school or taking them on family holidays (Green et al., "True Confessions"). Before her startling interview televised by "Turning Point," cameras captured her conferring with young William behind a bush at school. She was, she claimed, letting him know what she was about to do so the media stories would not surprise him (Hall 69; Green, et al., "True Confessions" 98).

Six magazines carried Diana's picture on the cover during the week following the "Turning Point" interview. Five of them were devoted to that story while one, Harper's Bazaar, did not even mention it. In the five that did, the texts sensationalized her adultery, her self-inflicted vomiting, and her self-inflicted wounds. Yet not one of these five articles neglected to publish a photograph of William and Harry with Diana (or once, alone), proving her cultural value as the mother of two little princes. The lone article that did not mention the interview had the following full-page announcement:

Her Royal Highness the Princess of Wales will visit the United States this month to be honored at United Cerebral Palsy's annual awards dinner for her philanthropic efforts-many of which improve the lives of children. To mark the occasion, she granted these photographs, taken by Patrick Demarchelier, to Harper's Bazaar ("Her Royal Highness" 162).

Harper's Bazaar apparently felt it significant to point out the obvious: that cerebral palsy affects children as well as adults. And Diana, the media tell us, cares about children.

The media also frequently shows Princess Diana with the elderly and the sick: people in need of attention and compassion (Lacey 32). In fact, Diana was the first royal to shake bare hands with an AIDS patient (before that, the royals wore gloves). The media approves this decision as what Lacey calls, "the single most moving and innovative royal gesture in decades" (32). What, after all, is a Princess these days but a nurturer for the whole country? Stripped of any political power, the royal family are figureheads, symbols to promote national unity and to represent their country abroad. Princess Diana declared she hopes not to be Queen of England, but to be "Queen of people's hearts" ("Turning Point" 1995).

The problem with the nurturing stereotype is not that no woman should ever be nurturing. It is that currently, all female-sexed persons from all walks of life are expected to nurture. That quality has been "naturalized" as an essential characteristic of women. Thus, for example, the media covered extensively the horrifying story of Susan Smith, who killed her own children in 1994, while giving much less spectacular media coverage to the multitude of men who kill their wives and children violently or harm them over time by withholding child 
support payments and forcing them into poverty. Furthermore, nurturing in contemporary society often becomes an additional "job" for women who have worked all day in underpaid positions. The time expended caring for spouse and children or elderly relatives after a full work day is time taken away from care of the self. Care of the self, including rest and private time, is vital for physical health, emotional well-being, and happiness. In the Princess Diana narrative, womens' happiness seems fleeting.

\section{Victim}

The press made Diana cry before Prince Charles did. From the engagement until now, the press has stalked her every waking moment. Diana and the palace have attempted to negotiate private space for her, but the deals always seem to fall through. Photographs of Diana in a bikini while she was noticeably pregnant caused an uproar. The scandal of a pregnant woman/princess wearing a garment considered sexual and suggestive lay behind the public outrage over the shamelessness of reporters that would stalk her and publish such photographs ( "Portrait of a Marriage" 31). Moreover, at other times the press published pictures of Diana in tears and reported the negative effects on Diana of the reporters' zealousness. The world sighed in sympathy as it bought the tabloids and rewarded the press' unkind behavior.

Since 1992, Prince Charles and the royal family have taken over from the press as the victimizers of Diana. Some speculation exists that the royal family chose Diana as a "breeder" to carry on the royal line (Paglia 23; Stratford 151). The public "knows" Prince Charles still loves his former and allegedly current lover, Camilla Parker Bowles, and that he wore the cufflinks she gave him on his wedding day. Furthermore, according to tabloids and bibliographers, Charles was envious of Diana's popularity and felt overshadowed by his wife. He was callous when she suffered her bouts of depression and her eating disorder. At mealtimes, according to one of Diana's biographers, Andrew Morton, the Prince sneered, "Is that going to reappear later? What a waste!" ("Dramatic Excerpts"). The list goes on.

When Princess Diana declared during a televised interview in 1995 that she had a love affair outside her marriage, quickly followed by the words "I loved him. I adored him," the media could still construct a female victim theme. For James Hewitt had betrayed the Princess' love by publishing their story in a tellall biography, Princess in Love. Said Diana during the interview, "I loved him. But I was terribly let down" (BBC, 1995). Following up the televised interview, print media characterized Diana as "love-starved" and "lonely" while Hewitt "boasted" and betrayed. Thus, the textual princess is a victim of a loveless marriage and of a vain lover who sold her secrets.

So far all of these portrayals of Diana have a common thread. Although the real Diana is very much in the public spotlight, she is consistently talked about in personal, private contexts: mothering, beauty, tears, sexuality, love, etc. Because the media "feminized" Diana so perfectly into the ideal woman image 
(beautiful, nurturing and victimized) she remained in the press and public eye during the marital difficulties in 1987 until after she split with Charles in 1992. I think any feminist critic would expect, as I did, that depictions of Diana would both decrease and be drastically less flattering as a "punishment" for leaving such a powerful man. But rather than damaging the Princess' popularity, a whole new spate of articles and books ensued. Intriguingly, two new themes have entered the discourse: the hysteric and the femme fatale. These roles are very much in keeping with femininity generally, and yet they are different, more dramatic. A feminine-versus-masculine opposition will not help us understand this change. Another rhetorical strategy must come into play here to help explain how the media reconciles Diana's decision to leave her Prince with its own attempts to make her a model, or at least a heroine, for women. I argue that whiteness-versus-color is the way the media makes a difference between the ideal woman and the dangerous woman Diana images represent.

\section{About White Women}

In the United States rhetoric concerning women from the far or near past frequently concerned white women of the bourgeois class. The qualities of the ideal woman in the Victorian age were specifically the qualities that a white and Christian culture valued in well-to-do women. "In this formulation of values lower class women were simply ignored," writes Gerda Lerner ("The Victorian Image" 90). And some white women and minority women are also in the lower classes, thus the intersection of gender, race and class is a complex negotiation.

Generally women and minorities have shared common ground as, first, property of white men and, second, as marginalized voices in the United States. Moreover, the pecking order of man-woman, white-black becomes an issue of major importance at critical historical junctures. For instance, in the late $1800 \mathrm{~s}$ when both white women and former slaves wanted the right to vote, white men chose to ally with black men. But the prejudiced politics of that time divided white and black women from each other, as it does today.

Diana texts are more interesting in what they do not say or show about race than what they do. I looked at four biographies of Diana trying to find a picture of her and a person of color in the same frame. I found one photograph of Diana ladling stew to two Zimbabwean children, while Zimbabwean officials look on (Morton, "Her New Life" 69). White journalists and Red Cross workers are also populous in the shot. She reportedly later found the event demeaning to both her and the children (Morton 69).

Minority names are absent from the royal genealogy as well. Diana reputedly has more English blood than either Charles or the Queen mother (Montgomery-Massingberd), because British royalty often marries European royalty while the English aristocracy intermarries. In fact, King George V changed his surname from Saxe-Coburg to Windsor in order to allay suspicions that the monarchy was pro-German (Murray-Brown 191). Looking at the lineage of 
Diana, no surnames strike me as other than European: Seymour, Fitzroy, Somerset, and Spencer. As Montgomery-Massingberd says, "The Princess' ancestry is naturally of great interest, bearing in mind that her lines are now part of the royal genealogy" (23). The naturalness of this interest in heredity was presumed by many authors covering the royal courtship (c.f., Spink; Montgomery-Massingberd). Why would I, in the United States, be interested rather than enraged at this continuance of unearned privilege? Moreover, why would we be interested in the bloodline unless we needed to judge or exclude certain types of blood.? What would constitute an impurity in this royal bloodline? Suffice to say, no person of color has ever occupied the British throne (while people of questionable sanity have). Yet our US media make race invisible when discussing Princess Diana.

To pursue the notion that texts of Diana are about white femininity, I find some contemporary articles have helpful descriptions of "white" as a race. First, Nakayama and Krizek (1995) talk about the social location of "white" as being at the center and as being the norm. They argue that "white" has no essential characteristics but rhetoric constitutes what it means to be white (293). Dyer describes whiteness as the absence of color, and as an invisible norm against which everything else stands out as different (45). Certainly no white person's skin is literally white but the signifier "white" has connotative meaning beyond skin (for instance, light, safety, good) (Dyer 142). Part of that meaning is a defense against being black (Di Pieri 124). Di Pieri explains,

Whiteness thus constitutes an impossible ideal, something perhaps to identify with, but certainly not something one could ever achieve absolutely because its identity derives from fluctuating points of social identification that in turn derive from the economic and cultural oppression of, in this particular instance, African-Americans (124).

This leads Di Pieri to conclude that whiteness is a hysterical response to an ideal that can never be, an ideal necessary for total control (123).

Dyer finds that Hollywood films associate whiteness with order, rationality, and rigidity while blackness represents disorder, irrationality, and looseness (145). Regarding the movie, Jezebel, he says it has to do with "the belief or suspicion that black people have in some sense more 'life' than whites" (152). In this context, "life" is associated with the body, the emotions, sensuality and spirituality. This definition is antagonistic to whiteness' emphasis on the mind and intellect-total rationality. Mary Ann Doane specifically describes representations of the "civilized" white woman as an exemplar of culture, racial purity and refinement ("Dark Continents" 212).

Moreover, the white woman exists in a complex relation to race and gender, as suggested earlier. She exists within the white center, but outside of power. She can at times speak for power, as a social worker or immigration officer, but cannot make the rules. The possibility, however, always exists that she may aid the "enemy," the Other, for she is not quite fixed in the elusive center.

Foucaul's concept of discipline may help us better understand how represen- 
tations of women might encourage "white" behavior by offering images of rewards (economic incentives, love, or fame) for rationality, order and rigidity. Texts of Diana with her castles, crowns, and gowns are influential as strategic rhetoric, a rhetoric that "resecure[s] the center, the place, for whites" (Nakayama and Krizek 295). Furthermore, texts of Diana disobeying patriarchal and royal tradition can offer disincentives to readers who consider disturbing white masculine privilege: photographs and narratives about a depressed Princess, a toothin princess, or a boozing Princess, for example. In my analysis I find that since the royal separation texts of Diana contain a new element of "life" or color, as I have just defined it. This color-ing makes the persona of Diana seem less familiar, less comfortable as the narrative struggles both to explain why the modern Cinderella did not live happily ever after and to diminish her influence as a central media icon upon the culture. Next I want to discuss the themes of Diana as hysteric and femme fatale that have surfaced in 1990s texts.

\section{Hysteric}

Diana, by many accounts, has been driven to emotional displays and psychiatric illness because of her need for love. In 1992, the US media incorporated eating disorders into the Diana text. While most tabloids disregarded one late 1980s attempt by the National Enquirer to question Diana's weight loss, suddenly in late 1991-92 it became "common" knowledge. In an appropriately serious tone, the Star, People Weekly and both the Prince's and Princess's biographers tell how these bouts with bulimia and/or anorexia started during the engagement as a response to stress, reappeared after William's birth and reappeared in 1987. The articles are accompanied by various pictures of Diana with a fuller figure, and two recurring pictures of Diana in two different dresses exposing one bony shoulder and a long, thin arm to the camera. Recently, The Examiner reported that Diana is taking Prozac (an anti-depressant) to halt her eating disorder.

People Weekly gave the story a cover and three pages, of which almost two pages were photographs. Despite the caption explaining the disease of bulimia (which seemingly brings a puzzling disease out of the shadows), the text of the article is a gossipy exposé of what she did and why. For example, the article reports that "at Windsor Castle, a footman caught her scarfing down an entire steak-and-kidney pie" (61). While admitting that the palace and Diana's friends refuse to answer questions about Diana's illness, the author of the article relies on two of Diana's unauthorized biographers and a psychiatric profile of the average bulimic patient to provide evidence that Diana suffers from the eating disorder. Diana's alleged doctor is described as a "fashionable physician" (62) rather than an efficient or respected one, demeaning the seriousness of her alleged health problems. With such a small attempt at journalistic accuracy and such a frivolous tone, the text downplays the seriousness of the disease for all women. Finally, the text suggests that even though Diana is in a hard spot, she must not forget to nurture others. Whatever happens to her personally, this 
article quotes Andrew Morton as saying, "it must be heartening to know that thousands of women have gone for help as a result of this publicity" (63).

But, the media does not agree which eating disorder Diana has. People and Andrew Morton (in his book) name it bulimia, while the National_Enquirer and Andrew Morton (writing for the Star) report that Diana is anorexic. Eating disorders are perhaps all interchangeable in this culture - they simply symbolize a woman's sad obsession with thinness (that would not exist outside of current cultural expectations). The two diseases are often linked in phrases with each other, but these reporters have not made that link; whereas they have made a link between Prozac, an anti-depressant, and the eating disorder, showing that her emotional state has affected her body.

At the same time, the media constructed a suicidal Diana. Her first attempt to harm herself allegedly occurred while she was pregnant and suffering under the strain of media popularity and royal duties. She threatened to kill herself, according to media accounts, and when Charles did not respond she threw herself down a flight of wooden stairs. Morton's first account of this fall depicts a mere accident: "As she paused on the top step of the long staircase, she lost her footing," he claims as if he were there (Star 1991). In 1992, Morton labeled the fall a suicide attempt and described Diana's purported others: "Stabbing shallow cuts on her thighs and arms with a pen knife. Throwing herself against a glass cabinet. Slicing her wrists with a razor" ("Her True Story"). Yet a number of years later Morton reports, "It should be emphasized that they were not serious attempts to take her life, but cries for help" ("Her New Life" 74).

As media take away the rationality of the Diana of the 1990s, they support the overall system of whiteness. The frequency with which the press glamorizes these hysteric moments shows that the press expects its readers to respond well to these issues. In the package of "Diana" as the media presents her, to be beautiful, bejeweled, and beloved does not exempt women from worrying about their weight and disliking themselves. In fact the ideal woman, actively pursuing femininity, exaggerates these very qualities. The proper attitude of the ideal woman is the "insatiable" desire to serve and please others through nurturing behavior and fulfilling beauty standards. Thus, it becomes even more understandable that to live up to public expectations, a princess would starve herself and hate herself for her perceived imperfections ... to the point of attempting to take her own life. But this excess of emotion, this hysteria, is life or color as we have defined it, not the cool rationality and orderliness of the ideal white person. This new hysteric image comes to play in the 1990s texts to represent a loss of "white" order or control. Moreover, the attempts at suicide and control of appetite mark the body, not the head. Sexuality in the image of the femme fatale will connote color for similar reasons.

\section{Femme Fatale}

Representations of the virgin bride have given way to images of a sexually experienced woman confident (manipulative at times) of her body in the 1990s. 
For instance in 1985 Diana joined Royal Ballet star William Sleep on stage for what was then a little publicized, surprise performance dedicated to her husband. Five years later in a People Weekly article titled, "The Woman Who Will Be Queen" (July 1990), the event earned one fairly large photo of her standing with Sleep on-stage with a tiny caption, but no lines in the main text. The same magazine did not make anything of the dance a few month's later in a "Collector's Edition Extra" about Diana. The Star reported the event with three photographs only in 1991. Then in 1996, the story reappeared in another People Weekly Extra with several pictures, captions, and written text, including comments by Sleep_-ten years later! The pictures are action shots of Diana dancing, twirling, jumping, wearing a low-cut, silver gown. Now, after the separation, the media shows us a younger Diana reveling in her body and moving with music.

Diana's sexuality made news from the very beginning of her relationship with Charles. The press ferreted out sources to attest to her virginity, as mentioned above. The media even pondered her name, Diana, for its mythical attachment to the Roman goddess of virginity (c.f., Lacey; Paglia). Diana's biographers treated her alleged sexual inexperience delicately. They also seemed to think they had to explain how a contemporary young woman could possibly still be a virgin. Lacey says, "She had the gift of making people feel they must look after her. She was a daughter, a girlfriend, a sister-never a mistress" (17). Morton explains that "there were lots of boyfriends, but none became lovers. The sense of destiny which Diana had felt from an early age shaped, albeit unconsciously, her relationships with the opposite sex" ("True Story" 44). Spink uses the metaphor of a "fresh, unblemished 'English rose"" to describe a sexually innocent Diana (75).

The narratives of her pre-wedding virginity have not changed in fifteen years (perhaps to reassure us that her sons are legitimate heirs to the throne). Writing in 1992, Morton, as quoted above, depicts the same premarital innocence as Montgomery-Massingberd, writing in 1982. What is now at stake is the narrative of Diana's awakened female sexuality as a dangerous force. Stories that broke in the late 1980s of gushy, affectionate phone calls between Diana and another man are mild compared to the Princess's verbal confession on national television that she had a three-year affair with Major James Hewitt. Could a perceived threat to the purity of the royal bloodline be responsible for the media frenzy over Diana's love life since the separation? While Diana confessed to one adulterous affair, articles in tabloids such as the Star and the National Enquirer have accused her of five such affairs-Hewitt, Oliver Soames, James Gilbey, David Waterhouse, and Philip Dunne — and of flirting suggestively with other men, like rugby player Will Carling (Lague; Denworth \& Terry).

People Weekly handled the topic of Di's infidelity more subtly than the newspaper tabloids. After her BBC interview in November 1995, the magazine dedicated only two paragraphs and one photo of its six-page spread to the affair, whereas the other tabloids exploited it immensely. However, in that story, titled "True Confessions," pictures of both Oliver Soames and James Gilbey 
indicate lingering suspicion about her honesty regarding their friendships. The three major tabloids, The Star, National Enquirer, and the Globe, created raunchy cover pages the week following the interview, all claiming to tell us what "censors slashed" or Diana "“didn't dare tell." The cover pages had such headlines as "Di's Sizzling Affair with the Lover I [sic] Adored" (Gould and Jones 24), "Truth about her sex life. The men who fight to share her bed. Her kinky, 'fatal attraction' affair" (Duffy 36), and "My forbidden trysts in hot tub, stable $\&$ garden . . . my lover unlocked my passion" (Bell 20). Gone are the gentle euphemisms of English roses.

The three tabloids agree that the Princess made the first move on Hewitt. Diana "embarked on an explosion of lust" (Duffy 36). These new representations of Diana are very earthy, very much about bodily pleasures as opposed to the purity and innocence of the previous decade. Perhaps the media respected Charles's ownership of Diana's sexuality (as her husband) while they were together. But now that she is single the media projects its own fantasies of aggressive female sexuality upon her image without fear of patriarchal retribution. In this way, the media also depicts the divorced woman as a threat to the nuclear family because of her sexuality rather than her independence from a male partner.

Just like the hysteric, the femme fatale threatens white order and rationality. The femme fatale, the siren of mythology, does not restrain her sexuality or her body according to patriarchal norms, threatening the ordered lives, rationality and, hence, the whiteness of the men who hear her call. This type of representation is thus another shade of color over the figure of the ideal white woman: the Diana of the 1980s. In the conclusion I will show that there has been no abrupt break in the media's depiction of Diana. These two newer themes of Diana as the hysteric and the femme fatale co-exist nicely with the older themes of Diana as beauty object, nurturer and victim, and allow the media to continue using hegemonic representations of Diana without loss of continuity.

\section{Conclusion}

The media could not do a 180-degree turn regarding Diana after she separated from Charles and still maintain credibility with their audiences. So the media frame sex mostly as the consolation of a lonely, neglected wife in the tabloids. "After it became clear that Charles wanted Camilla instead of her, Di was deeply lonely. She sought comfort in the arms of other men" (National Enquirer 12/5/95, 36). "Di's steamy romance started three months later-and three years after her cheating husband stopped making love to her" (Bell 24). By presenting Diana as reacting to her husband rather than instigating infidelity, the narratives preserve the victim ideology I wrote about above.

Similarly, some of the new texts about Diana also keep the nurturer image. Two of the three tabloids, People Weekly, and Newsweek, mention Diana's concern for her children. For instance, Diana told William about the interview before it happened to prepare him, and Diana wants William to be king rather 
than Charles (Hall, "Heir at Eton" 69; Green, Smith \& Wright, "True Confessions" 98; Duffy). According to Bell, Diana told Hewitt, "they must never, ever kiss or touch in front of her two young sons, Princes William and Harry" (24). These images may function less to protect Diana's purported femininity and more to protect the image of her sons as solid, uncorrupted heirs to the throne.

As whiteness and color are not essential characteristics but discursive constructions with material consequences, I am making no claims as to the "true" nature of races. Using Dyer's work on typical Hollywood representations of whiteness and blackness, I find that since Diana's separation from Prince Charles, her media images have lost degrees of whiteness. As an image of femininity, Diana is color-ed by textual emphasis on her as hysteric and femme fatale. In this way, the media disciplines images of Diana not by making her any less feminine, but by attempting to change her femininity from ideal to dangerous-from white to colored. Mary Ann Doane writes about the relation between images of white women and Hottentot prostitutes in colonialist discourse:

The white woman, in her unknown ability and sexual excessiveness does indeed have a close representational affiliation with blackness . . . what the representational affinity "slipping back" in a blackness comparable to prostitution. The white woman would be the weak point in the system, the signifier of the always too tenuous hold of civilization. (213-214)

Diana, as a white woman, has certainly become the weak point (or sore spot) in the system of royal privilege. She signifies the loosening grip of power over women's behavior at the same time that she illustrates how power tries to hold on to traditional representations. Moreover, the text implicitly suggests fear of tainting the royal blood and rendering royal power colored.

While I read as a critic messages constraining women's behavior in the texts, I see the material rewards for that behavior in those very same images: wealth, fame, children, and commemoration in history. Discipline both punishes and rewards in an attempt to maintain a stable level of social interactions. The repetition of similar symbols in discourse serves to naturalize and reinforce conditions by training people's expectations and by constraining discourse to a limited number of symbols. We like this authority when it keeps people obeying traffic signals and waiting their turns in line at grocery stores. But we must constantly be uncovering the human motivations behind disciplined actions, expectations, and images to move ourselves toward a more equitable system of relations among people.

Media representations of women, though fictional to a large extent, serve to remind the public of what women "are." From her appearance on the world scene as virgin bride to her victimization by the media and royal family alike, Diana serves white imperialist, capitalist, and sexist ideologies through the disciplining effect of the reification of her images. Her "feminine virtues" are repeated through media representations as part of a naturalizing and stabilizing feminine identity in contemporary Western discourse. As we know, US society 
uses those virtues as excuses to economically and socially exploit and oppress women. The test for feminists over these years has been to prove that the punishment of oppression - the lack of authority and of self-hood-is worse than the rewards offered under that yoke, including love and acceptance.

Because Diana separated from the "Great White Hope" (as she reportedly calls him) (Morton, "Her New Life" 9), the media had to smooth over a contradiction in its narrative about her as ideal. They attempted to tarnish her popular image with the introduction of new themes to the texts. Of course the audience has a space to resist this social disciplining. The text calls into being a subject position that is sexist, racist, and class-ist in order for its disciplining force to be completely effective. But no real person completely fills that subject position as created. So, critics can anticipate rejection, resistance, and reinterpretation. A "real" woman may celebrate the coloring of Diana's image, whether it be her new found sexuality or her feisty independence. The post-modern condition promises that cynicism, resistance, reclamation, and ignoring the discourse are some of the many ways people respond to spectacles of discipline.

\section{WORKS CITED}

Adler, Jerry, et al. “Diana's Battle Royal”. Newsweek 11 March 1996: 20-29. Barry, Stephen P. Royal Secrets: The View from Downstairs. NY: Villard Books, 1985.

“Battling Bulimia: Diana's Diet Ordeal." People Weekly 3 August 1992: 6062.

Bell, John. "Di Gets It All.” Globe 12 March 1996: 20.

"Forbidden Passions." Globe 5 December 1995: 24-25, 40.

Benson, Ross. Charles: The Untold Story. London: Victor Gollancz, 1993.

Billig, Michael. Talking of the Royal Family. NY: Routledge, 1992.

Blair, Carole, Julie R. Brown, and Leslie A. Baxter. "Disciplining the Feminine." Quarterly Journal of Speech 80 (1994): 383-409.

Burgheim, Richard A., Eric Levin, and Beth Filler. "A Decade of Diana." People Weekly. Collector's Edition Extra Fall 1990.

Caplan, Paula J. The Myth of Women's Masochism. Toronto: University of Toronto Press, 1993.

Cloud, Dana. "The Limits of Interpretation: Ambivalence and the Stereotype in Spenser: For Hire." Critical Studies in Mass Communication 9 (1992): 311-324.

"The Materiality of Discourse as Oxymoron: A Challenge to Critical Rhetoric.” Western Journal of Communication 58 (Summer 1994): 141-163.

"Hegemony or Concordance? The Rhetoric of Tokenism in Oprah Winfrey's Rags-to-Riches Biography." Critical Studies in Mass Communication 13 (1996): 115-137.

Coward, Rosalind. "The Royals." Female Desire. London: Paladin Books, 1984. 163-171.

Davies, Kathy, Julienne Dickey, and Teresa Stratford. Out of Focus: Writings 
on Women and the Media. London: Women's Press, Ltd., 1987.

"Upping the Anti in Feminist Theory." The Cultural Studies Reader. Ed., Simon During. New York: Routledge, 1993.

Decker, Linda. "Di's Nightmare War with Mental Illness." National Examiner 21 February 1995: 13.

Dimbleby, Jonathan. "The Private Prince." Newsweek 11 March 1996: 3237.

Di Piero, Thomas. "White Men Aren't." Camera Obscura 30 : 113-137.

Doane, Mary Ann. "Cyborgs, Origins, and Subjectivity." Coming to Terms: Feminism, Theory \& Politics. Ed., Elizabeth Weed. New York: Routledge, 1989. 209-214.

"Dark Continents: Epistemologies of Racial and Sexual Difference in Psychoanalysis and the Cinema." Femme Fatales: Feminism, Film Theory and Psychoanalysis New York: Routledge, 1991. 209-248.

"Film and the Masquerade: Theorizing the Female Spectator." Femme Fatales: Feminism, Film Theory and Psychoanalysis. New York: Routledge, 1991. 17-32.

Dow, Bonnie J. "Femininity and Feminism in Murphy Brown." Southern Communication Journal (1994): 143-155.

"Hegemony, Feminist Criticism, and The Mary Tyler Moore Show." Critical Studies in Mass Communication 7 (1990): 261-274.

"The Womanhood Rationale in the Woman Suffrage Rhetoric of Frances

E. Willard." Southern Communication Journal 56 (1991): 298-307

Dow, Bonnie J., and Mary Tonn. "Feminine Style and Political Judgment in the Rhetoric of Ann Richards." Quarterly Journal of Speech 79 (1993): 286-302.

Duffy, David. "Di Uncensored." Star 5 December 1995: 36-37.

Dyer, Richard. "White.” The Matter of Images: Essays on Representations. New York: Routledge, 1993. 141-163.

Eaton, Anne. "Charles \& Diana." The Star Summer 1991.

Elliott, Michael, et al. "I Won t Go Quietly." Newsweek 4 December 1995: 63-66.

Farrell, Mary H.J., et al. "The Woman Who Will Be Queen.” People Weekly 16 July 1990: 64-71.

Foucault, Michel. Discipline and Punish: The Birth of the Prison. New York: Random House, 1975.

Fraser, Nancy. Unruly Practices: Power, Discourse and Gender in Contemporary Social Theory. Minneapolis: University of Minneapolis Press, 1989.

Gould, Martin \& Jones, Barbara. “Di’s Sizzling Nights with Charmer Who Stole Her Heart." Star 5 December 1996: 24-25.

Green, Michelle, Terry Smith, Terry \& Margaret Wright. "True Confessions." People Weekly 4 Dec. 1995: 92-97.

Green, Michelle et al. "Diana's Secrets.” People Weekly 14 Sep. 1992: 106116.

."Prince of Wiles." People Weekly 16 July 1994: 28-33. 
. "Prince-Less Diana.” People Weekly 11 March 1996: 76-82.

"Di Launches a (Décolleté) Counteroffensive." People Weekly 14 Sep. 1994: 31 .

Hall, Carol. "The Heir at Eton: Prince William's New Home." Newsweek 4 Dec. 1995: 69.

Hall, Trevor. Born to Be King. Prince William of Wales. New York: Colour Library International Ltd., 1982.

"Her Royal Highness, the Princess of Wales: The New Portraits." Harper's Bazaar Dec. 1995: 162-167.

hooks, bell. "The Oppositional Gaze." In Black Looks: Race and Representation. Boston: South End Press, 1992.

Howell, Georgina. “Diana's Sweet Revenge-An Insider's Report from London.” McCall's Apr. 1995: 100-102.

Irving, Clive. "The Palace and the Image Machine." The Monarchy and Its Future. Ed. Jeremy Murray-Brown. Birkenhead, England: Allen \& Unwin, Ltd, 1969. 99-110.

Janaway, Alison. Diana: Her Latest Fashions. London: Colour Library Books, Ltd., 1984.

Jones, Barbara. "Cheatin' Charles Drives Diana to Drink." The Star 18 July 1995: 36-37.

Kromm, Jane E. "The Feminization of Madness in Visual Representation." Feminist Studies 20 (1994): 507-533.

Lacey, Robert. Princess. London: Times Books, 1982.

Lague, Louise. "Di’s New Style: A Shopper's Guide.” InStyle (September 1995): 110-117.

Lague, Louise and Vickie Bane. "Rocky Mountain Di and Her Boys Do Colorado." People Weekly (July 31, 1995): 44-45.

Langway, Lynn. "Diana: Fifteen Years of Great Style." Ladies Home Journal. June 1996: 136-139.

Levin, Eric, ed. "The Diana Years.” People Weekly Extra: Special Photo Issue. Spring 1996.

Mattelart, Michelle. Women, Media, Crisis: Femininity and Disorder. London: Comedia Publishing Group, 1986.

McGee, Michael Calvin. "Text, Context, and the Fragmentation of Contemporary Culture." Western Journal of Speech Communication 54.3 (1990): 274289.

Montgomery-Massingberd, Hugh. Diana: Princess of Wales. London: Fontana Paperbacks, 1982.

Morton, Andrew. "Diana: Dramatic Excerpts from the Book that Rocked Britain." People Weekly 22 June 1992: 84-103.

. "Diana-Her Life Alone." Newsweek 4 December 1995: 67-69.

_. Diana: Her True Story. NY: Simon \& Schuster, 1992.

. Diana: Her New Life. NY: Simon \& Schuster, 1994.

. "Diana: What Happened and Why." Life Aug. 1992: 26-32.

"Once upon a Time: From the First Kiss to the Final Break-the Twelve Years 
of Charles and Diana." Life Feb. 1993: 29-39.

Paglia, Camille. "The Diana Cult." The New Republic 3 Aug. 1992: 23-26.

Plamann, Steve. "Di's Secret Love Letters." Star 12 Dec. 1995: 10.

"Portrait of a Marriage: How the Fairytale Unraveled." Newsweek 22 June 1992: 68-74.

Radway, Janice. Reading the Romance: Women, Patriarchy and Popular Literature. Chapel Hill, NC: University of Chapel Hill Press, 1984.

Reed, Evelyn. "Class, Caste, or Oppressed Sex?" Rpt. in Feminist Frameworks: Alternative Theoretical Accounts of the Relations between Women and Men, $3^{\text {rd }}$ ed. Ed. Alison M. Jaggar \& Paula S. Rothenberg. NY: McGrawHill, 1993. 170-173.

Reid, Dixie. "Divorce Court." Sacramento Bee 4 March 1996: C-1, C-5.

Rushing, Janice Hocker. "Introduction to Feminist Criticism." The Southern Communication Journal 57.2 (1992): 83-8.

Sanz, Cynthia et al. "Some Kind of Magic." People Weekly 17 June 1996: 4247.

Spink, Katheryn. Invitation to a Royal Wedding. New York: Crown Books, Inc., 1981.

Taylor, John. Circus of Ambition: The Culture of Wealth and Power in the Eighties. New York: Warner Books, 1989.

van Zoonen, Liesbet. Feminist Media Studies. Thousand Oaks, CA: Sage Publications, Ltd., 1994.

Wallace, Carole, ed. "All About Diana: The Private World of a Princess." People Weekly Extra Spring 1988.

Welter, Barbara. "The Cult of True Womanhood: 1820-1860." Our American Sisters: Women in American Life and Thought. Ed. Jean E. Friedman \& William G. Shade. Boston: Allyn \& Bacon, Inc., 1973. 96-123.

“Will Di Ever Smile Again?” Star 12 March 1996: 58-59. 